\section{Development of a model for the estimation
of shear strength of discontinuity in massive \\ Development of a model for the estimation
of shear strength of discontinuity in massive and karstified limestone}

Rudarsko-geološko-naftni zbornik

(The Mining-Geology-Petroleum Engineering Bulletin) UDC: 622.2

DOI: 10.17794/rgn.2021.2.5

Original scientific paper

\author{
Ivana Dobrilović'; Petar Hrženjak²; Dražen Navratil ${ }^{3}$ \\ ${ }^{1}$ Našička 1, 10000 Zagreb \\ ${ }^{2}$ University of Zagreb, Faculty of Mining, Geology and Petroleum Engineering, Pierottijeva 6, 10000 Zagreb \\ ${ }^{3}$ Croatian Geological Survey, Sachsova 2, 10000 Zagreb
}

\begin{abstract}
In this paper, the problem of estimating the shear strength of discontinuity is presented, which especially occurs in massive and karstified limestones, where discontinuity walls can be extremely rough and irregular, with or without filling material, and for which the current models have proven to be unsatisfactory. A characteristic example of such limestones is the deposit of dimension stone "Kanfanar", located on the Istrian peninsula in Croatia. For the purpose of developing a model for estimating the shear strength of discontinuity, field research was conducted in which large samples of blocks with natural discontinuities were prepared, as well as samples of filling material in limited conditions, on which detailed laboratory tests of shear strength were performed. Special attention was paid to determining the joint roughness coefficient $J R C$, the actual contact area between the discontinuity walls, the basic or residual friction angle and the friction angle of the built-in filling material between the discontinuity surfaces. The development of the model for estimating the shear strength of discontinuity was based on Barton's JRC-JCS empirical model, given the fact that it is one of the most commonly applied models in engineering practice. Based on the results of the tests, a modification of Barton's JRC-JCS model was made, in such a way that the friction angle of the built-in filling material in the case of discontinuity with a filling was applied instead of the basic or residual friction angle. In addition, for the correct evaluation of the roughness of the discontinuity walls in massive and karstified limestones, it was found that it is necessary to increase the roughness coefficient to values larger than 20, which has been proposed as the maximum so far. Evaluation of the proposed model showed that it is satisfactorily accurate in estimating the shear strength of discontinuity with clay filling material of different states of consistency.
\end{abstract}

\title{
Keywords:
}

karst; discontinuity; shear strength; joint roughness coefficient; clay filling

\section{Introduction}

Determining the shear strength of discontinuities is of great importance, especially in conditions when the rock mass behaves as a discontinuous geotechnical media, i.e. when the fracture of the rock mass takes place mainly on discontinuity surfaces. For that reason, numerous studies have been undertaken around the world to determine, first of all, the shear mechanism and then the features that affect the shear strength of discontinuities. In doing so, given the large number of identified features that have an impact on both the shear mechanism and shear strength parameters, the research results have not always been very encouraging from the perspective of engineering application.

The systematic study of the shear mechanism of two opposite walls of discontinuities can be said to begin

Corresponding author: Ivana Dobrilović

idobrilo@gmail.com with Patton in 1966. He conducted detailed field and laboratory tests, taking Euler's model as a starting point (Patton, 1966). Due to the fact that if very small rock volumes are sampled, their intact characteristics can vary greatly, Patton conducted most laboratory tests on artificially prepared samples in such a way that the sample surfaces contained copies of actual irregularities of discontinuity walls. He used gypsum to make the samples, and thus he was able to achieve features most similar to those of homogeneous rocks. Shear strength tests were performed in a direct shear device. Based on the results of laboratory tests and field observations, he noticed that at low values of normal stresses, shear occurs on the surfaces of surface irregularities, whereas at high stresses, close to the peak values of compressive strength of materials, shear occurs through the intact part of the material. Therefore, by analysing the fracture envelope, Patton concluded that the mechanism of behaviour of jagged or rough surfaces of discontinuity walls during shear is best described by the bilinear model. He pro- 
posed a model for estimating the shear strength of discontinuity with the following equation:

Where:

$$
\tau=\sigma_{n} \tan \left(\varphi_{b}+i\right)
$$

$\tau$ - shear strength (MPa),

$\sigma_{n}$ - normal stress on the discontinuity surface (MPa),

$\varphi_{b}$ - basic friction angle (friction angle on a flat and smooth surface) $\left(^{\circ}\right)$,

$i$ - inclination (effective angle of irregularities) $\left({ }^{\circ}\right.$ ).

However, determining the effective angle of irregularities $i$, on the surfaces of which shear would occur in a wider range of possible values of normal stresses is not simple, i.e. it is almost impossible without testing. Assuming that the greatest wall roughness occurs on tensile cracks, Barton conducted very extensive laboratory tests on natural samples, but with artificially produced tensile cracks and roughness, that could be expected in nature (Barton, 1973). He performed shear strength tests at normal stresses with a range of values from 0.5 to 2 $\mathrm{MPa}$, with the basic friction angle ranging from 28.5 to $31^{\circ}$. Based on the test results, he found that the peak value of shear strength greatly depends on the roughness of the walls, the ratio of the values of uniaxial compressive strength of the walls and normal stress on the crack surface during shear. Following the statistical analysis of test results, Barton derived his empirical strength criterion in the form of the following equation:

$$
\tau=\sigma_{n} \tan \left(J R C \log _{10}\left(\frac{J C S}{\sigma_{n}}\right)+\varphi_{b}\right)
$$

Where:

$$
\begin{array}{ll}
\tau & - \text { shear strength (MPa), } \\
\sigma_{n} & - \text { normal stress on the discontinuity surface (MPa), } \\
\varphi_{b} & - \text { basic friction angle (friction angle on a flat and } \\
& \text { smooth surface) }\left({ }^{\circ}\right), \\
J R C & - \text { joint roughness coefficient (-), } \\
J C S & - \text { joint wall compressive strength (MPa). }
\end{array}
$$

For the introduced roughness coefficient $J R C$, which is the measure of the roughness of the discontinuity walls in a given shear area, Barton found that it ranges from approximately 0 to 20 , ranging from the smoothest to the roughest discontinuity wall. By readjusting the proposed Equation 1 for the empirical strength criterion, Barton also provided the equation for the calculation of the discontinuity roughness coefficient by back analysis, based on the results of the shear strength test:

$$
J R C=\frac{\tan ^{-1}\left(\frac{\tau}{\sigma_{n}}\right)-\varphi_{b}}{\log _{10}\left(\frac{J C S}{\sigma_{n}}\right)}
$$

Where:

$\tau$ - peak shear strength (MPa),

$\sigma_{n}-$ normal stress on the discontinuity surface (MPa), $\varphi_{b}$ - basic friction angle (friction angle on a flat, smooth and unweathered surface) $\left({ }^{\circ}\right)$,

$J C S$ - joint wall compressive strength (MPa).

Given that a large influence of roughness was established, i.e. of the $J R C$ roughness coefficient on the shear strength peak value, which is sometimes impossible to determine by back analysis, Barton and Choubey proposed standard roughness profiles, according to which values for measured profiles in the value range from 0 to 20 are determined by visual comparison (Barton and Choubey, 1977).

When using this method of determining the roughness coefficient, to obtain the most accurate $J R C$ values it is necessary to use handheld profilometers. In addition to the above, the authors found a certain decrease in the value of shear strength in weathered discontinuity walls, which is why they proposed the use of a residual angle $\varphi$, instead of the basic friction angle $\varphi_{b}$. Therefore, the final equation was proposed to estimate the peak value of the shear strength of discontinuities with weathered walls, as follows:

$$
\tau=\sigma_{n} \tan \left(J R C \log _{10}\left(\frac{J C S}{\sigma_{n}}\right)+\varphi_{r}\right)
$$

Where:

$\tau$ - peak shear strength (MPa),

$\sigma_{n}-$ normal stress on the discontinuity surface (MPa),

$\varphi_{r} \quad-$ residual friction angle (friction angle on the weathered wall of discontinuity) $\left(^{\circ}\right)$,

$J R C$ - joint roughness coefficient,

$J C S$ - joint wall compressive strength (MPa).

To determine the value of the residual friction angle on weathered walls $\varphi_{r}$, based on the results of index tests, i.e. the determination of hardness using the Schmidt hammer on weathered and unweathered walls, the authors proposed the following equation:

$$
\varphi_{r}=\left(\varphi_{b}-20\right)+20(r / R)
$$

Where:

$\varphi_{b}$ - basic friction angle (friction angle on a flat, smooth and unweathered surface) $\left(^{\circ}\right)$,

$r$ - Schmidt hardness determined on the weathered wall of the discontinuity,

$\mathrm{R}$ - Schmidt hardness determined on a dry and unweathered surface.

Similarly, a correction of the compressive strength of the $J C S$ discontinuity walls was proposed based on the degree of wear that can be easily determined from the ratio of Schmidt hardness on the weathered wall and hardness on the unweathered surface $(r / R)$. In actual engineering practice, when such direct measurements are impossible, in his first paper, Barton proposed that the degree of wear of discontinuity walls be determined by a simple estimate, during which a correction for the compressive strength of JCS walls is made, which, in the 
worst-case scenario, can drop to $1 / 4$ of the value of the uniaxial compressive strength of intact rock material (Barton, 1973). Furthermore, experimental studies on the scale effect on shear discontinuity characteristics, i.e. a decrease in the value of individual characteristics with the increase of dimensions of the examined samples, a significant effect of the discontinuity length on the shear strength and deformability of discontinuity was found (Bandis et al., 1981). The determined influence actually refers to the different involvement of the surface unevenness that controls the shear mechanism in relation to the different lengths of the discontinuity. This effect was also determined for the JRC roughness coefficient and the compressive strength of the $J C S$ discontinuity walls. Based on these results, Barton and Bandis later proposed corrections of these quantities with respect to the relevant discontinuity length that actually refers to the "in situ" block size expressed by Equations 6 and 7 (Barton and Bandis, 1982).

$$
\begin{aligned}
& J R C_{n}=J R C_{0}\left(\frac{L_{n}}{L_{0}}\right)^{-0,02 J R C_{0}} \\
& J C S_{n}=J C S_{0}\left(\frac{L_{n}}{L_{0}}\right)^{-0,03 J R C_{0}}
\end{aligned}
$$

Where:

$J R C_{n}$ - roughness coefficient for the relevant discontinuity length,

$J C S_{n}$ - compressive strength of the walls for the relevant discontinuity length (MPa),

$J R C_{0}-$ joint roughness coefficient on the sample,

$J C S_{0}$ - joint compressive strength on the sample (MPa),

$L_{0} \quad$ - length of the discontinuity surface on the sample $(0.1 \mathrm{~m})(\mathrm{m})$,

$L_{n} \quad$ - relevant discontinuity length (in situ block size) (m).

In addition to the proposed equations, Barton provided a diagram for an approximate estimate of the roughness coefficient $J R C_{n}$ based on the measured maximum roughness amplitude and the length of the measured roughness profile that can be applied in the field, i.e. on the relevant discontinuity length (Barton, 1982). Given the possibility of errors in determining the roughness coefficient $J R C$, and especially when compared with standard profiles, various statistical parameters were introduced, which are determined on the basis of digitized roughness profiles, and which are used to calculate $J R C$ values by applying established correlation functions. One of the most commonly used parameters, which also proved to be the best in estimating the value of the $J R C$ roughness coefficient, is $Z_{2}$ (the root mean square of the first derivative of the profile) which is given by the equation:

$$
Z_{2}=R M S\left(\frac{\Delta y}{\Delta x}\right)=\frac{1}{L} \sqrt{\int_{x=0}^{x=L}\left(\frac{d y}{d x}\right)^{2}}
$$

Where:

$L-$ total joint length ( $\mathrm{mm})$,

$\Delta x$ - sampling interval $(\mathrm{mm})$,

$\Delta y$ - difference between two adjacent sampling points (mm).

One of the first authors to apply the statistical parameter $Z_{2}$ were Tse and Cruden, who proposed a correlation function represented by Equation 9 to estimate the value of $J R C$, for which they obtained the correlation coefficient value of 0.986 (Tse and Cruden, 1979).

$$
J R C=32.2+32.47 \log _{10} Z_{2}
$$

Following them, a number of authors attempted to suggest better correlation functions based on their research (Yang et al., 2001; Tatone and Grasselli, 2010; Jang et al., 2014), which actually did not significantly improve the $J R C$ roughness coefficient estimate.

Briefly, the above is the basis of the JRC-JCS model proposed by Barton et al., which has become the most commonly used criterion to assess the shear strength of discontinuities in everyday engineering practice. In the last few decades, a number of researchers tried to suggest certain improvements to Barton's model or tried to provide entirely new empirical models. However, precisely due to the simplicity and comprehensibility of the model and the relatively simple way of determining the input quantities, Barton's basic model is still retained, although in some conditions it did not prove reliable enough (Singh and Basu, 2018). Table 1 provides an overview of only some of the characteristic suggestions for improvement or suggestions for completely new models. A more detailed presentation of existing empirical models for estimating the shear strength of natural discontinuities as well as their evaluation can be found in the work of Singh and Basu (Singh and Basu, 2018).

By presenting the equations of characteristic models (see Table 1), it can be concluded that there is a considerable diversity and complexity of individual concepts and of the number of input quantities. The reasons for this lie primarily in the fact that there is a big problem with the quantification of roughness, as well as its impact on the peak shear strength, as well as the actual contacts between the opposite walls of discontinuity during shear. Based on the analysis results of the applicability of individual models, it was determined to what extent their application can be applied in relation to the characteristics of cracks and types of materials (Singh and Basu, 2018).

Given the problem of quantification of roughness, which actually refers to the quantification of morphological features of discontinuity walls, Grasselli and Egger first introduced imaging of surfaces using a laser profilometer, based on which they obtained digital surface models using the triangulation algorithm (Grasselli and Egger, 2003). After that, they determined the distribution function of the corresponding surfaces for certain 
Table 1: Overview of characteristic models for estimating the shear strength of discontinuities

\begin{tabular}{|c|c|c|}
\hline References & Shear strength models & Equations \\
\hline Jing et al. (1992) & $\tau=\sigma_{n} \tan \left(\varphi_{b}+l_{0}\left(1-\frac{\sigma_{n}}{\sigma_{c}}\right)\right)^{k_{2}}$ & $(10)$ \\
\hline Kulatilake et al. (1995) & $\tau=\sigma_{n} \tan \left(\varphi_{b}+a(S R P)^{c}\left[\log _{10}\left(\frac{J C S}{\sigma_{n}}\right)\right]^{d}+I\right)$ & $(11)$ \\
\hline Zhao (1997) & $\tau=\sigma_{n} \tan \left[\varphi_{r}+J R C J C M \log _{10}\left(\frac{J C S}{\sigma_{N}}\right)\right]$ & $(12)$ \\
\hline Aydan et al. (1996) & $\tau=\left[c_{j}\left(1-\exp \left(-B_{1} \sigma_{n}\right)\right)+\sigma_{n}\left(\tan \varphi_{i}+A_{2} \exp \left(-B_{2} \sigma_{n}\right)\right)\right]$ & $(13)$ \\
\hline Grasselli and Egger (2003) & $\tau_{p}=\sigma_{n} \tan \left(\phi_{r}\right)\left(1+\exp \left(-\frac{1}{9 A_{0}} \frac{\theta_{\max }^{*}}{C} \frac{\sigma_{n}}{\sigma_{t}}\right)\right)$ & $(14)$ \\
\hline Tatone and Grasselli (2009) & $\tau=\sigma_{n} \tan \left[\phi_{b}+\left(\frac{\theta_{\max }^{*}}{C+1}\right)^{1.18 \cos \beta}\right] \times\left[1+\exp \left[-\frac{\theta_{\max }^{*}}{C+1} \frac{\sigma_{n}}{9 A_{0} \sigma_{t}}\right]\right]$ & $(15)$ \\
\hline Ghazvinian et al. (2012) & $\tau=\sigma_{n} \tan \varphi_{b}+i_{0} \frac{\left(/ \sigma_{n}\right)}{(\sigma /)^{a}}$ & $(16)$ \\
\hline Lee et al. (2014) & $\tau=\sigma_{n} \mid \tan \varphi_{b}+0,017(J R C)^{0,89}\left(\frac{J C S}{\sigma_{n}}\right)^{,, \tau}$ & $(15)$ \\
\hline Tang et al. (2014) & $\tau=\sigma_{n} \tan \mid \phi_{b}+10 \frac{A_{0} \theta_{\max }^{*}}{1+C} \frac{\left(/ \sigma_{n}\right)}{1+\left(\sigma_{t} /\right)}$ & $(16)$ \\
\hline Jang and Jang (2015) & $\tau=\sigma_{n}^{B} \tan \left(\varphi_{b}+\varphi_{j}+s_{n}\right)$ & $(17)$ \\
\hline Tang and Wong (2016) & $\tau_{p}=\sigma_{n} \tan \left[\phi_{b}+\left[\frac{1}{\left[1+8 A_{0} \theta_{\max }^{*} /(1+C) k\right]}\right] \frac{4 A_{0} \theta_{\max }^{*}}{C+1}\left[1+\exp \left(-\frac{1}{9 A_{0}} \frac{\theta_{\max }^{*}}{C+1} \frac{\sigma_{n}}{\sigma_{t}}\right)\right]\right.$ & $(18)$ \\
\hline
\end{tabular}

Notes:

$A_{0}$ - maximum possible contact area; $A_{2}, B_{l}, B_{2}$ - material coeficients; $a, b, c, d$ - material coeficients or fitting constants; $C$ - 3D roughness parameter; $i_{0}$ - Initial dilation angle; $I$ - Slope of the non-stationary joint surface, $J C S, \sigma_{C}$ - joint wall compressive strength, JMC - Joint Matching coeficient, JRC - Joint roughness coeficient, SRP - Stationary roughness profile, $k$ - Ratio of imposed dislocation $(d)$ to the length $(l)$ of sample along shear direction; $\mathrm{k}_{2}$ - Material constant/fitting constant; $\beta$ - Angle between foliation plane and shearing direction; $S_{n}$ - Shear component; $\varphi_{j}, \varphi_{A}$ - Joint roughness angle, $\varphi_{b}$ - Basic friction angle; $\varphi_{r}$ - Residual friction angle, $\sigma_{n}$ - Normal stress, $\sigma_{t}$ - Brazilian tensile strength of concerned rock, $\tau$ - Shear strength of discontinuity; $\theta_{\text {max }}{ }^{*}$ Maximum apparent gradient of asperity along shear direction.

slopes of unevenness in relation to the total potential contact surface of the walls during shear, whereby they obtained the roughness parameter $C$ by the regression analysis for the determined function. Based on the results of shear strength tests, they established a model which combines the stress conditions, i.e. the stress and tensile strength ratio with the determined function, which provides the effective angle of inclination of irregularities which will not break during shear but will contribute to the base angle of friction. However, in the application of this model, the problem of contacts between the discontinuity walls also arose.

Although Barton already observed that discontinuities in which the opposite walls are in full contact and those that are not display different shear behaviours, only Zhao tried to implement this fact in the model for estimating shear strength by Equation 12 (Zhao, 1997). Zhao proposed a way to quantify the overlap of opposite discontinuity walls using the dimensionless coefficient $J M C$ (Joint Matching Coefficient) ranging from 0.1 to 1 , 
with 0.1 referring to $10 \%$ and 1 to $100 \%$ of overlap of the discontinuity wall surfaces. However, as the proposed method of determining this coefficient, as well as the method of its introduction into the basic model with the aim of correcting the contribution of roughness to the base shear friction angle is greatly simplified, the model did not prove sufficiently applicable.

Finally, the basic assumption of all models for estimating the shear strength of discontinuities relates to their application in the case of discontinuity without filling. In the case of discontinuity with filling, in which the thickness of the filling is not significantly greater than the surface unevenness of the walls, so that during shear mutual contacts still occur, starting with Barton most of the other authors consider that each such case should be considered separately (Barton and Choubey, 1977), i.e. that the shear strength of the discontinuity should be determined by testing, which can, in fact, only be carried out properly by "in situ" testing. In the case of thicker fillings, when there are no contacts between the discontinuity walls during shear, the shear strength of the discontinuity depends exclusively on the shear strength parameters of the filling material, which can be determined by laboratory testing.

\section{Research methods}

\subsection{Identifying issues}

Determining the shear strength of discontinuities has proven particularly challenging in massive and/or thicklayered karstified limestones that are characteristic of dimension stone deposits. Namely, it is a known fact that the process of karstification creates specific morphological forms of sites such as: caverns, sinkholes, shafts, swallow-holes, karstic depressions, karstic fields and plateaus; however, apart from specific morphological forms of ground, the process of karstification can create specific morphological forms of discontinuity wall surfaces (Hrženjak et al., 2019). Through the process of karstification, which is actually a process of chemical wear of carbonate under the influence of water acting as a weak carbonic acid, the walls of certain discontinuities are dissolved, resulting in very irregular and rough surfaces with prominent irregularities on both a small and large scale. This proved to be the main problem when determining the shear strength of the discontinuity in the case of the dimension stone deposit "Kanfanar", in which underground exploitation was introduced by the room-and-pillar excavation method. Both globally and in Croatia, underground exploitation was introduced for several reasons, primarily for environmental, but also economic and other reasons (Cotman and Vujec, 1998). The development and introduction of underground mining has actually enabled the development of machines, such as chain cutters, that have become effective in this method of excavation. However, the underground meth- od of excavation gave rise to the need of dimensioning underground rooms, i.e. determining their stability. Apart from the problem of determining the strength of rock mass, the problem of determining the shear strength of discontinuities occurred in dimensioning underground rooms and pillars.

\subsection{Features of the dimension stone deposit "Kanfanar"}

The deposit of dimension stone "Kanfanar" consists of layered limestones of Cretaceous and Paleogene deposits which, in stratigraphic tectonic terms, belong to the Istrian plate, i.e. the western Istrian Jurassic-Cretaceous anticline (Cotman, 2006). The deposit is characterized by layered limestones of different thicknesses with quasi-horizontal subsidence, with a dip angle of up to $3^{\circ}$ towards the east (see Figure 1). The exploitation layers stratigraphically belong to the Kanfanar formation (KA) - lower apt, divided into several layers, whose total thickness ranges from 6.7 to $6.8 \mathrm{~m}$ (Matičec et al., 2013). Above the exploitation layers there is an immediate roof of $9.5 \mathrm{~m}$, whereof the first $4.5 \mathrm{~m}$ consist of compact and homogeneous limestones with similar physical and mechanical characteristics, as well as exploitation layers, which also belong to the Kanfanar formation (KA) - lower apt, while the remaining upper part consists of light, floury and shell limestones with much worse physical and mechanical material characteristics, that also belong to the Kanfanar formation (KA) - lower apt. The immediate roof is followed by younger deposits of the upper roof (Crna formation (CN) - upper alb), consisting of thin layers of limestones with marl interlayers and stratified marly limestones, which are karstified at the surface and mixed with red soil. The total thickness of the upper roof ranges from 5 to $10 \mathrm{~m}$ depending on the terrain.

In structural terms, in the deposit there are mainly two sets of discontinuities, the first extending approximately in the northwest-southeast direction and the second

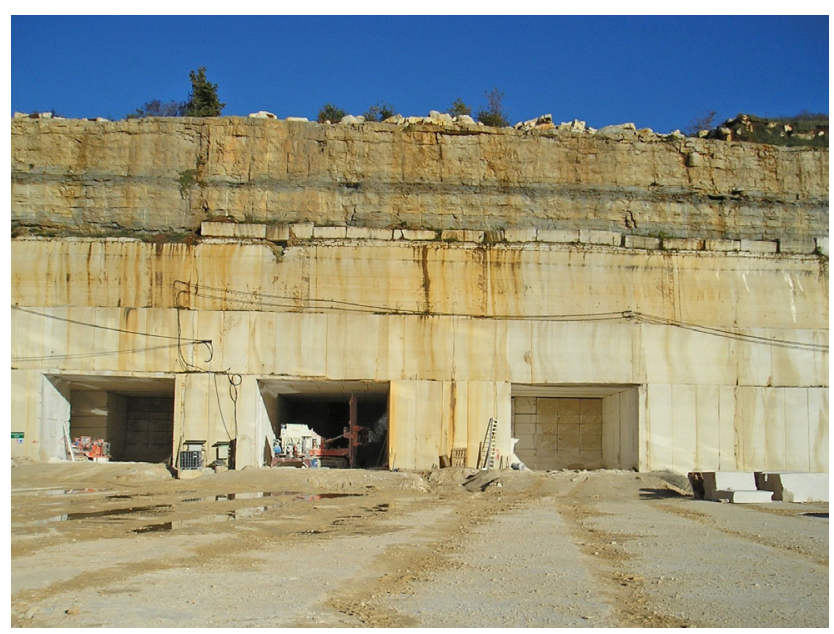

Figure 1: Dimension stone deposit Kanfanar 
northeast-southwest. The discontinuities are mainly subvertical to vertical with smaller variations of the dip angle from $85^{\circ}$ to $90^{\circ}$, but with significantly larger variations in the strike angle, of up to $\pm 30^{\circ}$. The sets of discontinuity can thus mutually close angles of $60^{\circ}$ to $120^{\circ}$. The persistence of discontinuity is very large, mostly greater than $30 \mathrm{~m}$, whereby the discontinuities continuously intersect both the exploitation deposits and the deposits of the immediate roof and floor. Since the spacing between the discontinuities is extremely wide $(>6 \mathrm{~m})$, the deposit is, conclusively, built of massive rocks with very large rock blocks that are separated by rather prominent discontinuities, i.e. characteristic discontinuities (Hrženjak et al., 2014). For both types of discontinuities, it was found that the discontinuity walls were wavy-rough on the more regular parts of the accessible surfaces. By comparing them with standard roughness profiles, the value of the joint roughness coefficient $J R C_{0}$ in the range of classes from 10-12 to 14-16 was obtained. However, on the more irregular parts of the discontinuity surfaces, irregularities were found that were significantly larger than those presented on the standard roughness profiles. The size of the aperture was found to range from 3-10, 5-15 and $15-50 \mathrm{~mm}$, indicating that the discontinuities have a moderately wide, and wide to very wide aperture. Furthermore, it was found that the filling material unevenly fills the free space between the discontinuity walls, appearing in almost all possible combinations, i.e. that either there is no filling material because it has been washed away, or that it occurs only partially, or to the point where the material completely fills the free space between the walls. Based on such discontinuity characteristics in the bedrock mass, no realistic conditions and possibilities were found for conducting in situ tests by which relevant values of shear strength parameters for the identified sets of discontinuity could be obtained. Therefore, detailed laboratory tests were performed in order to determine a model for estimating the shear strength of discontinuities in massive and karstified limestones.

\subsection{Sampling and testing methods}

Given the large irregularities and roughness of the discontinuity walls, it was estimated that stone samples with natural discontinuity surfaces must be significantly larger in order to obtain representative results of shear strength of discontinuity by laboratory testing. In this sense, sampling was performed in such a way that a block of stone with the approximate dimensions of 150 $\times 130 \times 300 \mathrm{~cm}$ was first excavated out of the deposit, from which then samples of appropriate dimensions for laboratory tests were prepared. The stone block was extracted from the first exploitation layer containing the discontinuity surface from the first set of discontinuity. Samples for laboratory tests were prepared by sawing the block with diamond saws, so that samples of approximate dimensions of $150 \times(200-400) \times 300 \mathrm{~mm}$ with a discontinuity surface in the middle section of the sample were obtained. In addition to these, samples without a discontinuity surface were prepared, i.e. samples with a surface sawed through intact material for determining the basic friction angle, of approximately $150 \times 100 \times$ $300 \mathrm{~mm}$. The basic friction angle was determined by a simple "tilt" test according to the method suggested by ISRM (Alejano et al., 2018) and standard testing of the shear strength by direct shear under constant normal load $(C N L)$, also suggested by ISRM (Muralha et al., 2014), according to which the tests of peak strength of discontinuity with and without filling material were also performed.

The filling material from the discontinuity was sampled at several positions within the exploitation layers to obtain a sufficient amount and averageness of content required for laboratory tests for the purpose of determining the properties that affect the shear strength of filled discontinuities. In addition to the mineral composition, the plasticity states were determined according to the HRN EN ISO 17892-12:2018 standard, furthermore the grain size distribution was established according to HRN EN ISO 17892-4: 2016, the density of solid particles was determined according to HRN EN ISO 17892-3: 2016 and the carbonate content was established according to HRN U.B1.026: 1968.

Discontinuity characteristics were established according to the suggested methods for the quantitative description of discontinuity in rock masses (ISRM, 1978). The roughness coefficient $J R C$ was determined in two ways: in the first, it was determined as proposed by the authors (Barton and Choubey, 1977) - by taking the shape of the discontinuity wall surface using a profilometer and comparing it with the proposed standard profiles to which the $J R C_{10}$ values from 0 to 20 were added. Given the possibility of subjectivity in this method of determination, in the second method the non-contact measurement was applied, using the ShapeMetriX3D system (Navratil, 2011). With this method, discontinuity surfaces are recorded with stereo pairs of digital photographs, on the basis of which digital surfaces are created using ShapeMetriX3D software and discontinuity wall profiles are created. Based on the digital profiles, the values of the statistical parameter $Z_{2}$ were first calculated according to Equation 8, after which the values of the joint roughness coefficient $J R C_{10}$ were calculated using Equation 9. The uniaxial compressive strength of the discontinuity walls JCS was determined by Schmidt's hammer in accordance with the recommendations of ISRM (Aydin, 2009), through which the values of hardness on the walls and on the unweathered intact material were obtained. The values of the uniaxial compressive strength of discontinuity walls were calculated based on the uniaxial compressive strength of the intact rock material and the degree of wear of the walls, which was determined from the ratio of Schmidt hardness on the weathered wall $(r)$ and the hardness on the unweathered 
surface of the intact material $(R)$. An L-type Schmidt hammer was used in the test.

\section{Research results}

\subsection{Basic friction angle}

The basic friction angle was determined by the "tilt" test on a specially designed device for testing larger blocks, which was developed for this purpose in the Geomechanical Laboratory at the Faculty of Mining, Geology and Petroleum Engineering in accordance with test recommendations (see Figure 2). Three sets of samples were examined, each in five experiments. The statistical processing of the test results yielded an average value of the basic friction angle of $36.0^{\circ}$, with a standard deviation of 2.73 . The lowest value of $32.0^{\circ}$ and the highest value of $39.6^{\circ}$ were measured.

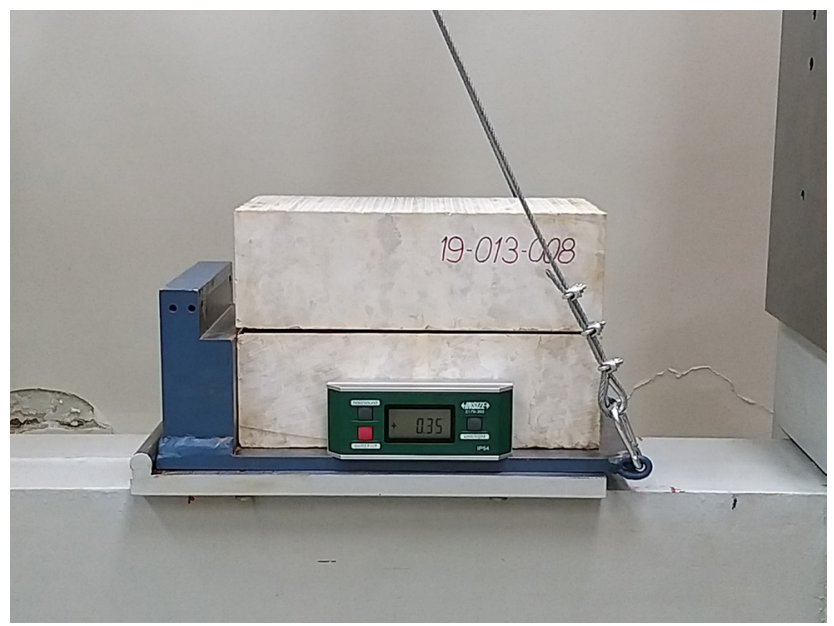

Figure 2: Tilt test

Due to the possible influence of a number of factors on the results obtained by the "tilt" test (Alejano et al., 2018), the basic friction angle was also determined by the standard shear strength test in CNL conditions. The test was performed on one set of samples with values of normal stresses of $0.75 \mathrm{MPa}, 1.5 \mathrm{MPa}$ and $3 \mathrm{MPa}$ and with a shear rate of $0.5 \mathrm{~mm} / \mathrm{min}$. By processing the test results for the obtained peak values of shear strengths in relation to the values of normal stresses, the direction of Coulomb strength was obtained by regression analysis, based on which the value of the basic friction angle of $38.2^{\circ}$ with the determination coefficient $\mathrm{R}^{2}$ of 0.9913 was obtained.

\subsection{Filling material features}

The tests for the filling material were carried out in the soil and rock testing laboratory of the company Geotehnički studio d.o.o. from Zagreb and in the laboratory of the Department of Geology at the Croatian Geological Survey. A granulometric analysis, the determina- tion of plasticity states (Atterberg limits), carbonate content, solid particle density and shear strength parameters were performed in the laboratory for soil and rock testing, while an analysis of mineral composition was performed at the laboratory of the Department of Geology at the Croatian Geological Survey. Since the mineral composition of the filling has an effect on shear strength, a semi-quantitative mineralogical analysis was performed using the X-ray diffraction (XRD) method. The analysis showed that the filling sample from the discontinuity consists of $44 \%$ kaolinite, whereas the other minerals in the entire sample were: $12 \%$ quartz, $10 \%$ calcite, $19 \%$ gibbsite, $3 \%$ hematite, $1 \%$ goethite and $11 \%$ chlorite. The results of determining the granulometry analysis are shown in Table 2, and the results of determining parameters that describe plasticity states in Table 3 . The test results show that this is a sample of high plasticity clay $(\mathrm{CH})$ containing detritus.

Table 2: Grain size distribution of the filling material

\begin{tabular}{|l|c|}
\hline Grain diameter & Distribution (\%) \\
\hline $63 \mathrm{~mm}-20 \mathrm{~mm}$ & 0.4 \\
\hline $20 \mathrm{~mm}-6.3 \mathrm{~mm}$ & 1.3 \\
\hline $6.3 \mathrm{~mm}-2 \mathrm{~mm}$ & 0.6 \\
\hline $2 \mathrm{~mm}-0.63 \mathrm{~mm}$ & 0.3 \\
\hline $0.63 \mathrm{~mm}-0.2 \mathrm{~mm}$ & 0.4 \\
\hline $0.2 \mathrm{~mm}-0.063 \mathrm{~mm}$ & 0.6 \\
\hline $0.063 \mathrm{~mm}-0.002 \mathrm{~mm}$ & 16.2 \\
\hline$<0.002 \mathrm{~mm}$ & 70.2 \\
\hline
\end{tabular}

Table 3: Plasticity states of filling materials

\begin{tabular}{|l|c|}
\hline Filling characteristics & Results \\
\hline Liquid limit, $\mathrm{w}_{\mathrm{L}}(\%)$ & 70 \\
\hline Plasticity limit, $\mathrm{w}_{\mathrm{P}}(\%)$ & 29 \\
\hline Linear shrinkage, $\mathrm{w}_{\mathrm{S}}(\%)$ & 18 \\
\hline Plasticity index, $\mathrm{I}_{\mathrm{p}}(\%)$ & 41 \\
\hline$\rho_{\mathrm{s}}\left(\mathrm{g} / \mathrm{cm}^{3}\right)$ & 2.65 \\
\hline $\mathrm{CaCO}_{3}(\%)$ & 21 \\
\hline Moisture content, $\mathrm{w}(\%)$ & 3.96 \\
\hline Classification symbol & $\mathrm{CH}$ \\
\hline
\end{tabular}

The shear strength parameters of the filling material were determined by the standard test procedure according to the ASTM D 3080/3080M-11 standard on laboratory-prepared (reconstructed) samples. Since different possible states of the filling material were determined in certain parts of the deposit, from completely dry to the state of almost liquid, but also spots where the filling material is completely washed away, the following limit states of filling material were selected for which laboratory samples were prepared: case $\mathrm{CH} 1$ actually refers to the discontinuity without filling, case $\mathrm{CH} 2$ - high plastic- 
ity clay $(\mathrm{CH})$ filling including grains $<2 \mathrm{~mm}$ in diameter in the dry state; case $\mathrm{CH} 3$ - high plasticity clay $(\mathrm{CH})$ filling including grains with a diameter $<0.4 \mathrm{~mm}$, prepared for a moisture content at liquid limit of $70 \%$ and case $\mathrm{CH} 4$ - high plasticity clay $(\mathrm{CH})$ filling including grains with a diameter of $<6.3 \mathrm{~mm}$, prepared for a moisture content of $45 \%$. The test results are shown in Table 4.

Table 4: Parameters of shear strength of filling material

\begin{tabular}{|l|c|c|c|}
\hline State of the filling & $\mathbf{w}(\mathbf{\%})$ & $\mathbf{c}(\mathbf{k P a})$ & $\boldsymbol{\varphi}\left(^{\circ}\right)$ \\
\hline Case $\mathrm{CH} 2$ & - & 0.6 & 35.8 \\
\hline Case CH3 & 70 & - & 15.1 \\
\hline Case CH4 & 45 & 11.3 & 26.6 \\
\hline
\end{tabular}

As the test results of shear strength discontinuity with fillings, presented by several authors, showed that a significant reduction in shear strength occurs by adding even a thin layer of filling (Indraratna and Haque, 2000), additional shear strength tests were performed in which the filling was installed between the samples surfaces on which the basic friction angle was determined. Additional tests were therefore performed in exactly the same way and with the same samples as in the case of determining the basic friction angle, but with built-in fillings between the sawed sample surfaces (see Figure 3). The tests were performed for all three filling states, with an average filling thickness of 2 to $3 \mathrm{~mm}$.

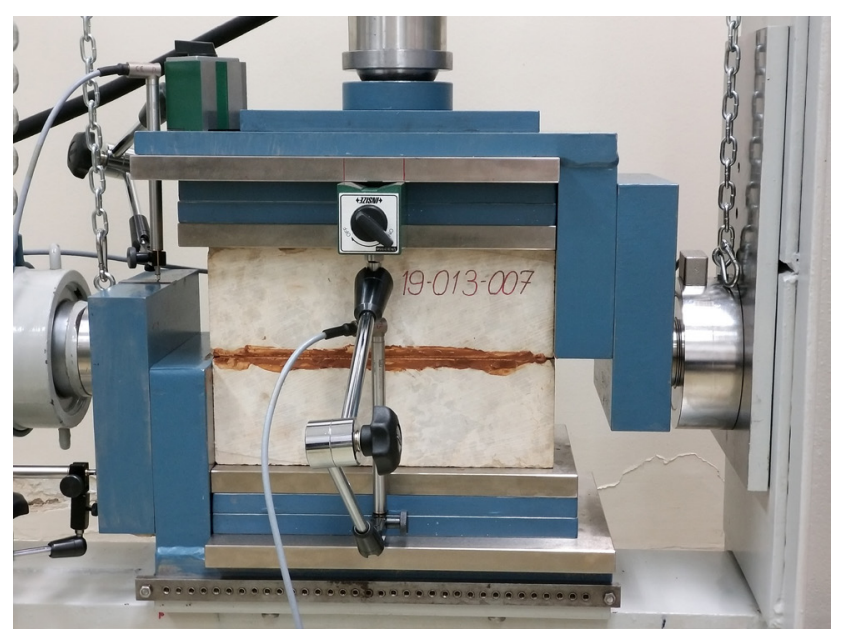

Figure 3: Shear strength test of the built-in filling

By statistical processing of the results of the "tilt" test, in the case of the $\mathrm{CH} 2$ filling the average value of the friction angle of $25.9^{\circ}$ was obtained, with a standard deviation of 3.27. The lowest value of $17.7^{\circ}$ and the highest value of $28.6^{\circ}$ were measured. For the case of the $\mathrm{CH} 3$ filling, an average value of the friction angle of $11.0^{\circ}$ was obtained, with a value of standard deviation of 1.71 and a minimum value of $8.4^{\circ}$ and a maximum value of $14.6^{\circ}$. In the case of the $\mathrm{CH} 4$ filling, the average value of friction angle of $33.4^{\circ}$ was obtained with a standard deviation of 6.61 and a minimum value of $24.9^{\circ}$ and a maximum value of $49.1^{\circ}$.

The friction angle of the built-in filling was also determined by the standard shear strength test in CNL conditions with values of normal stresses of $0.75 \mathrm{MPa}, 1.5 \mathrm{MPa}$ and $3 \mathrm{MPa}$ and a shear rate of $0.5 \mathrm{~mm} / \mathrm{min}$. By processing the test results for the obtained peak values of shear strengths in relation to the values of normal stresses, the directions of Coulomb strength were determined, on the basis of which the value of the friction angle was obtained. In the case of the $\mathrm{CH} 2$ filling, the friction angle value of $24.9^{\circ}$ was obtained with a $\mathrm{R}^{2}$ coefficient of determination of 0.9994. For the case of the $\mathrm{CH} 3$ filling, the value of the friction angle of $12.0^{\circ}$ was obtained with the $\mathrm{R}^{2}$ coefficient of determination of 0.9986 . In the case of the $\mathrm{CH} 4$ filling, the value of the friction angle of $12.6^{\circ}$ was obtained with the $\mathrm{R}^{2}$ coefficient of determination of 0.9994 .

\subsection{Discontinuity features}

For the purpose of determining the shear strength of the discontinuity, a total of six samples of stone blocks were prepared, which contained natural discontinuity surfaces in their central part. Three profiles were placed on each sample, which were plotted on both the lower and upper part of the sample (see Figure 4). The values of the roughness coefficients were then determined on each profile as described in Section 2.3. The uniaxial compressive strength of discontinuity walls was determined based on the uniaxial compressive strength value of intact rock material, which for the first exploitation layer from which samples were taken was $115 \mathrm{MPa}$ (Briševac et al., 2017) and the degree of wear was determined by Schmidt's hammer.

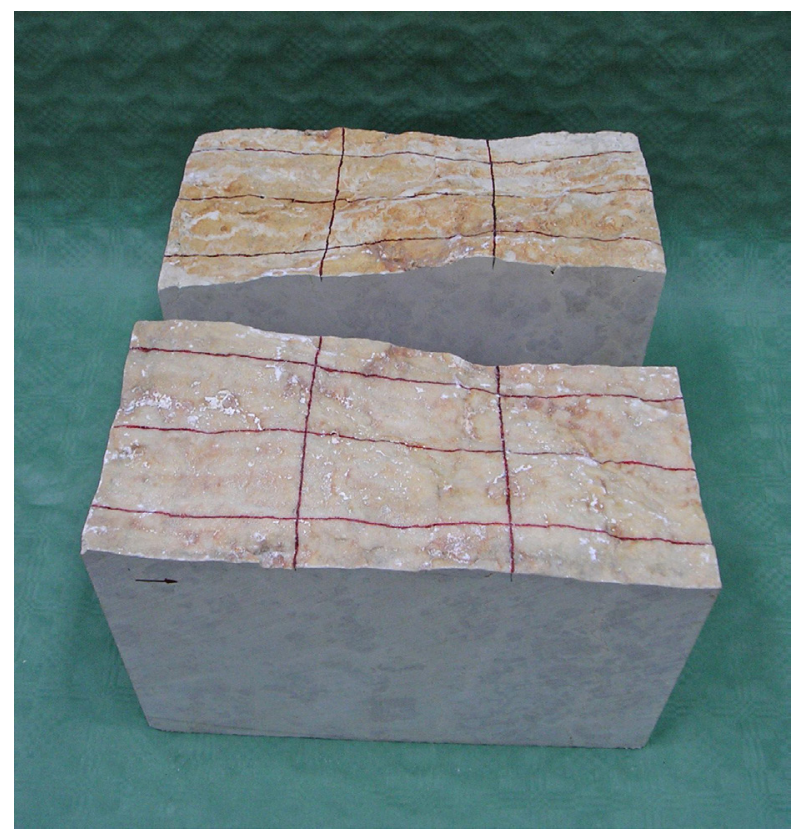

Figure 4: Example of a sample with plotted profiles on the discontinuity surface 
In addition to the above, the plotted profiles were accurately transferred to graph paper using a profilometer, taking special care to maintain the value of the aperture between the profile lines of the lower and upper part of the sample (see Figure 5). The average amount of aperture was obtained based on the measurement of the actual aperture between the profile lines, which was determined at every centimetre of length along the profile.

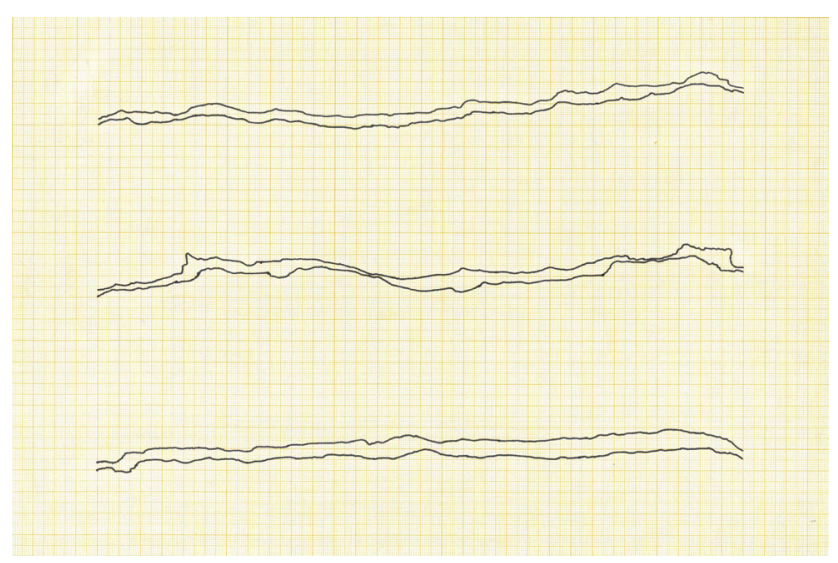

Figure 5: Example of plotted discontinuity surface profiles

Since a large irregularity and mismatch of the discontinuity walls has already been observed in preliminary research, great attention was paid to determining this feature. Zhao's proposal to introduce a Joint Matching Coefficient JMC (Zhao, 1997) proved to be oversimplified and therefore unreliable. Based on observations and measurements performed in this study, it was proposed to introduce a dimensionless coefficient called JCC (Joint Contact Coefficient) which represents the ratio of the surface area of the walls in contact to the total surface area of the sample discontinuity. Of the several tried and tested techniques for determining the $J C C$, the simplest technique proved to be an indigo and graph paper print. Indigo and graph papers were inserted between the plastic foils and then into the discontinuity, after which a certain loading of the sample was carried out. As the indigo paper subsequently stained a portion of the graph paper at the point where the contact of the opposite walls of discontinuity occurred, it was possible to calculate the percentage of wall matching. The results of determining the values of all discontinuity features described above are shown in Table 5.

Table 5: Features of discontinuity walls

\begin{tabular}{|l|l|l|l|l|l|}
\hline Sample & $\mathbf{J R C}_{\mathbf{1 0}}$ & $\mathbf{J R C}_{\mathbf{1 0}}\left(\mathbf{Z}_{\mathbf{2}}\right)$ & $\begin{array}{l}\text { JCS } \\
\mathbf{( M P a})\end{array}$ & $\begin{array}{l}\text { Aperture } \\
(\mathbf{m m})\end{array}$ & $\mathbf{J C C}$ \\
\hline 001DSR & 17.3 & 15.4 & 89.7 & 2.6 & 0.02 \\
\hline 002DSR & 14.7 & 17.4 & 97.8 & 2.8 & 0.06 \\
\hline 003DSR & 27.3 & 23.0 & 94.6 & 3.5 & 0.23 \\
\hline 004DSR & 16.7 & 18.8 & 88.8 & 4.8 & 0.01 \\
\hline 005DSR & 20.0 & 19.8 & 92.0 & 5.5 & 0.02 \\
\hline 006DSR & 22.0 & 19.5 & 90.5 & 4.3 & 0.12 \\
\hline
\end{tabular}

\subsection{Shear strength of discontinuities}

As already mentioned, the shear strength of the discontinuity was determined by the direct shear test method as suggested by ISRM (Muralha et al., 2014) under conditions of constant normal load (CNL) with and without filling material. The tests were performed on a device for direct shear of large soil and rock samples, which was developed for this purpose at the Geomechanical Laboratory of the Faculty of Mining, Geology and Petroleum Engineering, University of Zagreb (Gradiški et al., 2017). In order to determine the peak values of the friction angle on the discontinuity surfaces, the tests were performed at the lowest possible values of normal stresses, which were achieved only due to the weight of the upper part of the specimen itself, steel plates and the steel jaw required for shear stress transmission (see Figure 6). The results of the tests are shown in Table 6. The parameter $j_{r, f b}\left({ }^{\circ}\right)$ in the given table refers to the residual friction angle of the discontinuity walls in the case of the shear strength test without filling, i.e. the friction angle obtained by testing the built-in filling between the sawed surfaces, the values of which are shown in Section 3.2. The value $\mathrm{j}_{\text {peak }}\left({ }^{\circ}\right)$ refers to the peak friction angle, $\mathrm{d}_{\text {peak }}(\mathrm{mm})$ to the shear displacement when the shear strength peak is reached, and $\mathrm{y}_{\text {peak }}\left({ }^{\circ}\right)$ to the peak value of the dilatation angle.

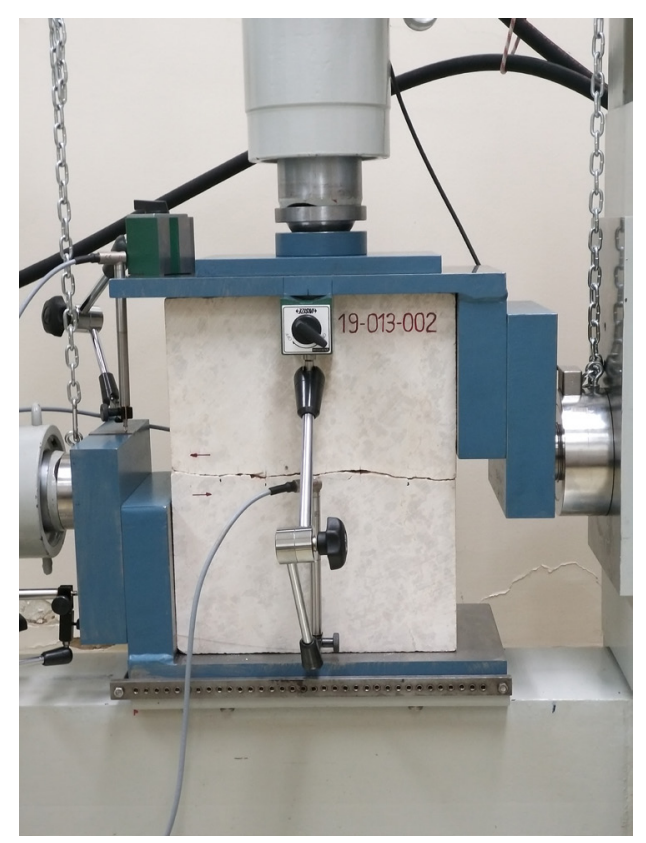

Figure 6: Shear strength test of discontinuities

Based on the results obtained for the shear strength peak values, the values of the roughness coefficients $J R C_{n B C}$ were calculated by back analyses using Equation 3. Since the tests were performed on samples with a discontinuity surface length of $30 \mathrm{~cm}$, necessary corrections were made for the sake of comparison with the previously estimated values of the roughness coefficients in 
Table 6: Shear strength test results

\begin{tabular}{|c|c|c|c|c|c|c|c|}
\hline Sample & $\varphi_{\mathrm{r}, \mathrm{fb}}\left({ }^{\circ}\right)$ & Filling thickness (mm) & $\sigma_{n}(\mathrm{MPa})$ & $\tau$ (MPa) & $\varphi_{\text {peak }}\left({ }^{\circ}\right)$ & $\delta_{\text {peak }}(\mathbf{m m})$ & $\Psi_{\text {peak }}\left({ }^{\circ}\right)$ \\
\hline 001DSR-CNL-CH1 & 33.8 & - & 0.017 & 0.026 & 56.0 & 0.7 & 10.8 \\
\hline 001DSR-CNL-CH2 & 24.9 & 3.2 & 0.017 & 0.037 & 64.8 & 3.3 & 10.4 \\
\hline 001DSR-CNL-CH3 & 12.0 & 2.4 & 0.021 & 0.079 & 75.2 & 1.2 & 28.6 \\
\hline 001DSR-CNL-CH4 & 12.6 & 2.1 & 0.016 & 0.017 & 46.3 & 1.5 & 2.3 \\
\hline 002DSR-CNL-CH1 & 35.2 & - & 0.019 & 0.065 & 73.3 & 2.3 & 20.6 \\
\hline 002DSR-CNL-CH2 & 24.9 & 3.2 & 0.018 & 0.038 & 64.7 & 2.4 & 8.2 \\
\hline 002DSR-CNL-CH3 & 12.0 & 2.0 & 0.019 & 0.050 & 69.4 & 2.7 & 17.0 \\
\hline 002DSR-CNL-CH4 & 12.6 & 2.5 & 0.018 & 0.038 & 64.8 & 4.5 & 10.9 \\
\hline 003DSR-CNL-CH1 & 34.7 & - & 0.021 & 0.155 & 82.4 & 1.3 & 20.6 \\
\hline 003DSR-CNL-CH2 & 24.9 & 3.4 & 0.018 & 0.060 & 73.7 & 2.0 & 10.9 \\
\hline 003DSR-CNL-CH3 & 12.0 & 2.5 & 0.018 & 0.063 & 74.1 & 2.3 & 22.0 \\
\hline 003DSR-CNL-CH4 & 12.6 & 2.7 & 0.018 & 0.053 & 71.5 & 2.2 & 19.8 \\
\hline 004DSR-CNL-CH1 & 33.6 & - & 0.021 & 0.039 & 62.3 & 1.8 & 17.1 \\
\hline 004DSR-CNL-CH2 & 24.9 & 3.4 & 0.021 & 0.025 & 49.1 & 2.4 & 0.1 \\
\hline 004DSR-CNL-CH3 & 12.0 & 2.3 & 0.021 & 0.038 & 61.0 & 2.5 & 14.3 \\
\hline 004DSR-CNL-CH4 & 12.6 & 2.8 & 0.024 & 0.027 & 48.1 & 3.7 & 7.6 \\
\hline 005DSR-CNL-CH1 & 34.2 & - & 0.019 & 0.081 & 76.6 & 0.6 & 10.9 \\
\hline 005DSR-CNL-CH2 & 24.9 & 3.1 & 0.021 & 0.039 & 62.4 & 2.5 & 5.5 \\
\hline 005DSR-CNL-CH3 & 12.0 & 2.3 & 0.020 & 0.051 & 68.7 & 2.0 & 11.2 \\
\hline 005DSR-CNL-CH4 & 12.6 & 2.9 & 0.021 & 0.037 & 60.7 & 4.4 & 10.8 \\
\hline 006DSR-CNL-CH1 & 33.9 & - & 0.038 & 0.213 & 80.0 & 0.9 & 48.9 \\
\hline 006DSR-CNL-CH2 & 24.9 & 3.0 & 0.031 & 0.141 & 77.6 & 3.2 & 11.9 \\
\hline 006DSR-CNL-CH3 & 12.0 & 2.3 & 0.031 & 0.127 & 76.4 & 1.9 & 20.5 \\
\hline 006DSR-CNL-CH4 & 12.6 & 3.0 & 0.029 & 0.110 & 75.4 & 3.1 & 15.3 \\
\hline
\end{tabular}

Table 7: Results of performed corrections and back analyses for values of roughness coefficients

\begin{tabular}{|l|c|c|c|}
\hline Sample & $\mathbf{J R C}_{\mathbf{n 1 0}}$ & $\mathbf{J R C}_{\mathbf{n Z 2}}$ & $\mathbf{J R C}_{\mathbf{n B C}}$ \\
\hline 001DSR & 11.7 & 11.0 & 6.0 \\
\hline 002DSR & 10.6 & 11.8 & 10.3 \\
\hline 003DSR & 15.0 & 13.8 & 13.1 \\
\hline 004DSR & 11.5 & 12.4 & 7.9 \\
\hline 005DSR & 12.9 & 12.7 & 11.5 \\
\hline 006DSR & 13.5 & 12.7 & 13.7 \\
\hline
\end{tabular}

the observation scale of $10 \mathrm{~cm}$. By applying Equation 6, the values for the roughness coefficient $J R C_{n I 0}$ were calculated, obtained on the basis of the value of $J R C_{10}$ and the roughness coefficient $J R C_{n Z 2}$, obtained on the basis of the value of $J R C_{10}\left(Z_{2}\right)$. A comparative presentation of the corrected values of the roughness coefficients with values of the back analyses is given in Table 7 .

\subsection{Development of the model for estimating the shear strength of discontinuities}

The main goal of developing the model was to establish a unique model for estimating the shear strength of very irregular and rough discontinuities with and without clay filling materials. The starting point for developing the model were the previous observations of Indraratna and Hague related to the phenomenon that a significant reduction in shear strength occurs when even a thin layer of filling is added (Indraratna and Haque, 2000). In doing so, Barton's JRC-JCS model was taken as the starting model, since it has been one of the most commonly used and therefore tested models in engineering practice so far. The basic assumption was that in the same way as the basic, i.e. residual friction angle contributes to the shear strength of the discontinuity without filling, so does the friction angle obtained by testing the built-in filling between the sawed surfaces contribute to the shear strength of the discontinuity with filling. Therefore, a model was set in the form of the following equation:

$$
\tau=\sigma_{n} \tan \left(J R C \log _{10}\left(\frac{J C S}{\sigma_{n}}\right)+\varphi_{r, f b}\right)
$$

Where:

$\tau$ - shear strength (MPa),

$\sigma_{n}-$ normal stress on the discontinuity surface (MPa),

$\varphi_{r f f}$ - residual or friction angle of the built-in filling material $\left(^{\circ}\right)$, 
Table 8: Presentation of test values and estimates of peak shear strengths

\begin{tabular}{|l|c|c|c|c|c|c|}
\hline Sample & $\left.\boldsymbol{\varphi}_{\mathbf{r}, \mathbf{f b}} \mathbf{(}^{\circ}\right)$ & $\boldsymbol{\sigma}_{\mathbf{n}}(\mathbf{M P a})$ & $\begin{array}{c}\text { Measured t } \\
(\mathbf{M P a})\end{array}$ & $\begin{array}{c}\text { Estimated } \boldsymbol{\tau} \text { by } \\
\mathbf{J R C}_{\mathbf{n} 10}(\mathbf{M P a})\end{array}$ & $\begin{array}{c}\text { Estimated } \boldsymbol{\tau} \text { by } \\
\mathbf{J R C}_{\mathbf{n Z 2}}(\mathbf{M P a})\end{array}$ & $\begin{array}{c}\text { Estimated } \boldsymbol{\tau} \text { by } \\
\mathbf{J R C}_{\mathbf{n B C}}(\mathbf{M P a})\end{array}$ \\
\hline 001DSR-CNL-CH1 & 33.8 & 0.017 & 0.026 & 0.076 & 0.062 & 0.025 \\
\hline 001DSR-CNL-CH2 & 24.9 & 0.017 & 0.037 & 0.043 & 0.038 & 0.018 \\
\hline 001DSR-CNL-CH4 & 12.6 & 0.016 & 0.017 & 0.024 & 0.022 & 0.011 \\
\hline 002DSR-CNL-CH1 & 35.2 & 0.019 & 0.065 & 0.069 & 0.098 & 0.064 \\
\hline 002DSR-CNL-CH2 & 24.9 & 0.018 & 0.038 & 0.038 & 0.047 & 0.036 \\
\hline 002DSR-CNL-CH4 & 12.6 & 0.018 & 0.038 & 0.023 & 0.027 & 0.022 \\
\hline 003DSR-CNL-CH2 & 24.9 & 0.018 & 0.060 & 0.110 & 0.074 & 0.061 \\
\hline 003DSR-CNL-CH4 & 12.6 & 0.018 & 0.053 & 0.045 & 0.037 & 0.033 \\
\hline 004DSR-CNL-CH1 & 33.6 & 0.021 & 0.039 & 0.080 & 0.104 & 0.040 \\
\hline 004DSR-CNL-CH2 & 24.9 & 0.021 & 0.025 & 0.049 & 0.057 & 0.028 \\
\hline 004DSR-CNL-CH4 & 12.6 & 0.024 & 0.027 & 0.033 & 0.037 & 0.021 \\
\hline 005DSR-CNL-CH1 & 34.2 & 0.019 & 0.081 & 0.131 & 0.120 & 0.080 \\
\hline 005DSR-CNL-CH2 & 24.9 & 0.021 & 0.039 & 0.064 & 0.062 & 0.049 \\
\hline 005DSR-CNL-CH4 & 12.6 & 0.021 & 0.037 & 0.036 & 0.035 & 0.029 \\
\hline 006DSR-CNL-CH1 & 33.9 & 0.038 & 0.213 & 0.205 & 0.162 & 0.219 \\
\hline 006DSR-CNL-CH2 & 24.9 & 0.031 & 0.141 & 0.094 & 0.080 & 0.098 \\
\hline 006DSR-CNL-CH4 & 12.6 & 0.029 & 0.110 & 0.050 & 0.045 & 0.051 \\
\hline
\end{tabular}

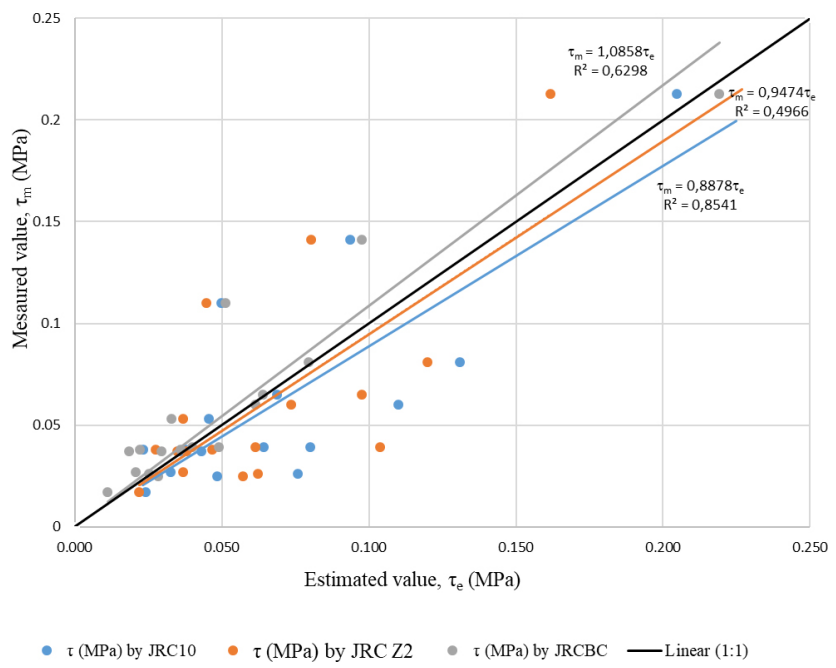

Figure 7: Presentation of the regression analysis results for the proposed model

$J R C$ - joint roughness coefficient, JCS - joint compressive strength (MPa).

Based on the proposed equation, an estimate of the peak shear strength for the examined cases of discontinuity with and without filling and of the established values of roughness coefficients was made, the results of which are shown in Table 8. The evaluation of the set model was performed by regression analysis, using RMS, average error and slope because those parameters are the best for representing relationships between estimated and measured values. Average error (estimated in the same way as indicated by Kulatilake et al., 1995),
Table 9: Statistical parameters of the successful application of the proposed model

\begin{tabular}{|l|c|c|c|c|}
\hline Proposed model & Average error & RMS & Slope & $\mathbf{R}^{\mathbf{2}}$ \\
\hline Using JRC $_{\mathrm{n} 10}$ & 49.08 & 0.0313 & 0.8878 & 0.6298 \\
\hline Using JRC $_{\mathrm{nZ2}}$ & 52.67 & 0.0351 & 0.9474 & 0.4966 \\
\hline Using JRC $_{\mathrm{nBC}}$ & 20.57 & 0.0197 & 1.0858 & 0.8541 \\
\hline
\end{tabular}

root mean square (RMS), and slopes of the best-fit lines in the estimated vs. measured shear strength plots were determined (Singh and Basu, 2018). The slope of the best-fit line was calculated using the following equation:

$$
\hat{B}=\left(\frac{S_{x y}}{S_{x x}}\right)=\frac{\sum_{i=1}^{n} x_{i} y_{i}-\frac{\left(\sum_{i=1}^{n} x_{i}\right)\left(\sum_{i=1}^{n} y_{i}\right)}{n}}{\sum_{i=1}^{n} x_{i}^{2}-\frac{\sum_{i=1}^{n} x_{i}}{n}}
$$

Where:

$\hat{B}$ - the slope of the best fit line,

$x_{i}$ - estimated shear strengths (MPa).

$y_{i}-$ measured shear strength (MPa).

The results are shown in the diagram in Figure 7 and Table 9.

\section{Discussion}

In order to determine the shear strength of discontinuities in massive and/or thick-layered, karstified lime- 
stones, field research was conducted on a characteristic deposit of dimension stone "Kanfanar", and detailed laboratory tests were performed on large stone samples with natural discontinuity surfaces from the deposit, as well as on filling material samples prepared for certain limit conditions. It was found that the process of karstification can create areas of discontinuity with very irregular and rough walls and prominent irregularities on both a small and large scale of observation. In addition, it has been found that discontinuities can be without filling or in most cases with filling material in different states of consistency. Since it has been proven that the existing models for shear strength assessment cannot provide satisfactory results for such examples of discontinuity, a detailed study was conducted with the aim of developing a better model.

The results of testing the basic friction angle by the "tilt" test show considerable variations in the obtained values, from $32.0^{\circ}$ to $39.6^{\circ}$, based on which an average value of $36.0^{\circ}$ was obtained. The dispersion of values can be attributed to the characteristics of individual grains that were in contact with each other and micro irregularities on the sawed surfaces, which was mentioned in the recommended method (Alejano et al., 2018), although measurements of planarity and surface smoothness showed that these meet the prescribed values. On the other hand, the standard shear strength test in CNL conditions resulted in the basic friction angle value of $38.2^{\circ}$ with a coefficient of determination of 0.9913 , which indicates greater consistency of the obtained values, i.e. a lesser influence of surface feature variations in this test.

Similar to these results, the results of the friction angle test of the built-in filling were obtained, i.e. the values of the friction angle obtained were much more consistent in the case of the standard shear strength test in CNL conditions compared to the tilt test. In addition, for the limit states of the filling material the standard shear strength test on average yielded significantly lower values of the friction angle of the built-in filling than the value of the friction angle of the filling material itself. From all of the above, it can be concluded that for determining the basic friction angle, and especially the friction angle of the filling material which is built in between the sample surfaces, the standard shear strength test in CNL conditions is pertinent.

Given the characteristics of the karstified discontinuity walls when determining the roughness coefficient $J R C_{10}$ (see Table 5), an extrapolation of the values was required, i.e. taking higher values than the maximum presented value for the standard roughness profiles proposed by Barton and Choubey (Barton and Choubey, 1977). The appropriateness of this is also proven by the $J R C_{10}$ values obtained on the basis of the statistical parameter $Z_{2}$ from the digital profiles of the discontinuity surfaces. Finally, by comparing the corrected values of these coefficients with the values of roughness coeffi- cients obtained by back analysis, a fairly strong correlation of their values was found, except in two cases - samples 001DSR and 004DSR (see Table 7) for which the back analysis displayed significantly lower values of roughness coefficients. The reason for this can primarily be attributed to the extremely small contact surface between the discontinuity walls, which prevents the contact of rougher parts during shear. This was subsequently established by analysing all the results of the shear strength test. Namely, in the case of extremely rough and irregular walls of discontinuity, where there is no complete overlap, the actual contacts can be located in smoother parts of the surface, which results in the appearance of seemingly less roughness in smaller shear displacements.

The tests of shear strength of discontinuity revealed several characteristic phenomena. First, shear strength discontinuity tests with built-in fillings of limit conditions $\mathrm{CH} 2$ and $\mathrm{CH} 4$ yielded, as expected, significantly lower values than cases without fillings. In contrast, shear strength tests with $\mathrm{CH} 3$ limit state fillings, which actually refer to high plasticity $(\mathrm{CH})$ clay fillings including grains $<0.4 \mathrm{~mm}$ in diameter, prepared for the moisture content at liquid limit of $70 \%$, resulted in shear strength values which, on average, were closer to the values without fillings than with fillings. The main reason for this is the observed mechanism of the extrusion of the filling. Namely, when there is shearing of discontinuities with extremely rough and irregular walls, which are in contact in only a few places due to mutual mismatch, the filling is completely squeezed out at the contact points, so that the shearing actually takes place without filling. In the case of fillings where the moisture content was not at the liquid limit $(\mathrm{CH} 2$ and $\mathrm{CH} 4)$, the extrusion occurs to a lesser extent, so that a filling of a certain thickness remains between the walls, which is, however, sufficient to significantly reduce the shear strength. Furthermore, precisely because of the extrusion effect of the filling during shear, it has been observed that thicknesses larger than 2-3 mm of built-in fillings essentially do not have any additional effect on the reduction of shear strengths. Secondly, shear strength discontinuity tests with built-in fillings of limit states $\mathrm{CH} 2$ and $\mathrm{CH} 4$ showed increased compressibility and decreased dilatation, in contrast to the shear strength tests without fillings, that showed significantly lower compressibility but higher dilatation, which is consistent with the results of other researchers (Indraratna \& Haque, 2000).

Based on the above, the evaluation of the successful application of the modified Barton JRC-JCS model was performed by regression analysis for cases without filling and for cases with built-in fillings of limit conditions $\mathrm{CH} 2$ and $\mathrm{CH} 4$ in relation to cases of determining JRC roughness coefficients.

The obtained statistical parameters (Average error, RMSE, $\mathrm{R}^{2}$, Slope), by which the performance of a par- 
ticular model can be evaluated the best, show a fairly good applicability compared to the obtained performance evaluation parameters of other models presented by Singh and Basu in their work (Singh and Basu, 2018). For most of the models presented in the introductory part, these authors obtained average error values ranging from 10.0 to 192.68 , for RMSE from 0.085 to 1.444 , and for slope values from 0.35 to 1.31 . It should be noted that these values referred to models for estimating the shear strength of discontinuities without fillings. Regarding the application of $J R C$, the regression analysis of the model shows that the estimated values of shear strengths obtained by the roughness coefficient determined via statistical parameter $Z_{2}$ based on digitized profiles are closest to the tested mean values. When the roughness coefficients were determined by comparing them with standard profiles, somewhat overestimated shear strength values were obtained, while, when roughness coefficients were determined by back analysis, slightly underestimated shear strength values were obtained.

\section{Conclusion}

The development of the model for estimating the shear strength of discontinuity was based on Barton's JRC-JCS empirical model, given the fact that it is one of the most commonly applied models in engineering practice. Based on the results of the tests, a modification of Barton's JRC-JCS model was made in such a way that the friction angle of the built-in filling material in the case of discontinuity with a filling was used instead of the basic or residual friction angle. It was found that the correct values of the friction angle for the clay filling material can be obtained only by the standard shear strength test in CNL conditions, in which the filling material is built in between the sawed surfaces of stone samples from which the basic friction angle is otherwise determined. Apart from this, for the exact evaluation of very irregular and rough walls of discontinuities in massive and/or thick-layered and karstified limestones, it was found that the joint roughness coefficient $J R C_{10}$ must be increased to values higher than the previously proposed maximum of 20 . The joint roughness coefficient $J R C_{10}$ was best evaluated by its determined correlations with the statistical parameter $Z_{2}$ on the basis of digitized discontinuity surface profiles. The evaluation of the proposed model proved that the model is accurate enough in estimating the shear strength of discontinuity with high plasticity clay filling material of different states of consistency.

\section{References}

ASTM D 3080 / 3080M-11 Standard test method for direct shear test under consolidated drained conditions, ASTM International, West Conhohocken, PA, www.astm.org, pages $1-9$.
Alejano, L.R., Muralha, J., Ulusay, R., Li, C.C., Perez-Rey, I., Karakul, H., Chryssanthakis, P., Aydan, O. (2018): ISRM Suggested method for determining the basic friction angle of planar rock surfaces by means of tilt tests. Rock Mechanics and Rock Engineering, 51, 3853-3859, DOI: 10.1007/s00603-018-1627-6.

Aydan, O., Shimizu, Y. Kawamoto, T. (1996): The anisotropy of surface morphology characteristic of rock discontinuities. Rock Mechanics and Rock Engineering, 29, 47-59, DOI:10,1007/BF01019939.

Aydin, A. (2009): ISRM Suggested method for determination of the Schmidt hammer rebound hardness: Revised version. International Journal of Rock Mechanics \& Mining Sciences, 46, 627-634,DOI:10.1016/j.ijrmms.2008.01.020.

Bandis, S., Lumsden, A.C., Barton, N. (1981): Experimental studies of scale effects on the shear behaviour of rock joints. International Journal of Rock Mechanics and Mining Science and Geomechanics Abstracts, 18, 1-21, DOI:10/1016/0148-9062(81)90262-X.

Barton, N. (1973): Review of a new shear-strength criterion for rock joints. Engineering Geology, 7, 287-332, DOI:10.1016./0013/-7952/(73)90113-6.

Barton, N. (1982): Modelling rock joint behavior from in situ block tests: Implications for nuclear waste repository design. ONWI-308, Columbus, OH, 96.

Barton, N., Bandis, S. (1982): Effects of block size on the shear behaviour of jointed rock. 23rd U.S. Symposium on Rock Mechanics, Berkeley, CA, 739-760.

Barton, N., Choubey, V. (1977): The shear strength of rock joints in theory and practice. Rock Mechanics, 10, 1-54, DOI:10.1007/BF01261801.

Briševac, Z., Hrženjak, P., Cotman, I. (2017): Estimate of Uniaxial Compressive Strength and Young's Modulus of the Elasticity of Natural Stone Giallo d'Istria. Procedia Engineering, 191,434-441. DOI:10.1016/j.proeng.2017.05.201.

Cotman, I. (2006): Glavni rudarski projekt podzemne eksploatacije - tipski (Main mining project of underground exploitation - typical). Kamen d.d. Pazin. (in Croatian, unpublished).

Cotman, I., Vujes, S. (1998): Planiranje i početna iskustva podzemnog otkopavanja arhitektonsko-građevnog kamena $\mathrm{u}$ Istri (Planing and starting experience of underground exploitation of dimension stone in Istria - Croatia). Rudarsko-geološko-naftni zbornik, 10, 63-72. (in Croatian with English abstract).

Ghazvinian, A.H., Azinfar, M.J., Vaneghi, R.G. (2012): Importance of tensile strength on the shear behaviour of discontinuities. Rock Mechanics and Rock Engineering, 45, 349-359.

Gradiški, K., Mulabdić, M., Minažek, K. (2017): Selected results of determining the friction interaction coefficient between crushed stone and polyester strip. Rudarsko-geološko-naftni zbornik (The Mining-Geological-Petroleum Engineering Bulletin), 32, 4, 37-43.

Grasselli, G., Egger, P. (2003): Constitutive law for the shear strength of rock joints based on three-dimensional surface parameters. International Journal of Rock Mechanics and Mining Science, 40, 25-40, DOI:10.1016/S1365-1609 (02)00101-6. 
Indraratna, B., Haque, A. (2000): Shear behaviour of rock joints. A.A. Balkema, Rotterdam, $164 \mathrm{p}$.

HRN EN ISO 17892-3:2016 Geotechnical investigation and testing - Laboratory testing of soil - Part 3: Determination of particle density (ISO 17892-3:2015; EN ISO 178923:2015).

HRN EN ISO 17892-4:2016 Geotechnical investigation and testing - Laboratory testing of soil - Part 4: Determination of particle size distribution (ISO 17892-4:2016; EN ISO 17892-4:2016).

HRN EN ISO 17892-12:2018 Geotechnical investigation and testing - Laboratory testing of soil - Part 12: Determination of liquid and plastic limits (ISO 17892-12:2018; EN ISO 17892-12:2018).

ISRM (1978) Suggested methods for the quantitative description of discontinuities in rock masses. International Journal of Rock Mechanics and Mining Sciences and Geotechnical Abstracts, 15, 319-368.

Hrženjak, P., Dobrilović, I. and Navratil, D. (2019): Problemi određivanja značajki stijenki karakterističnih diskontinuiteta $\mathrm{u}$ kršu (The problems of determining walls features of characteristic discontinuities in karts). $8^{\text {th }}$ Conference of Croatian Geotechnical Society and ISRM Specialised Conference, 211-217, 470 p. (in Croatian with English abstract).

Hrženjak, P., Jaguljnjak-Lazarević, A., Briševac, Z. (2014): Istraživanje stabilnosti podzemnih prostorija kamenoloma arhitektonsko-građevnog kamena na eksploatacijskom polju "Kanfanar-jug" (Investigation of the stability of the underground rooms of the dimension stone quarry on the exploitation field "Kanfanar-south"). Rudarsko-geološkonaftni fakultet Sveučilišta u Zagrebu. (in Croatian, unpublished).

Jang, H.S., Jang, B.A. (2015): New method for shear strength determination of unfilled, unweathered rock joint. Rock Mechanics and Rock Engineering, 48, 1515-1534, DOI:10.1007/s00603-014-0660-3.

Jang, H.S., Kang, S.S., Jang, B.A. (2014): Determination of joint roughness coefficients using roughness parameters. Rock Mechanics and Rock Engineering, 47, 2061-2073, DOI:10.1007/s00603-013-0535-z.

Jing, I., Nordlund, E., Stephansson, O. (1992): An experimental study on the anisotropy and stress-dependency of strength and deformability of rock joints. International Journal of Rock Mechanics and Mining Science and Geomechanics Abstracts, 29, 535-542, DOI:10.1016/01489062(92)91611-8.

Kulatilake, P.H.S.W., Shou, G., Huang, T.H., Morgan, R.M. (1995): New peak shear strength criteria for anisotropic rock joints. International Journal of Rock Mechanics and Mining Science and Geomechanics Abstracts, 32, 673697, DOI:10.1016/0148-9062(95)00022-9.

Lee, Y.K., Park, J.W., Song, J.J. (2014): Model for the shear behaviour of rock joints under CNL and CNS conditions. International Journal of Rock Mechanics and Mining Science, $70,252-263$.
Matičec, D., Fuček, L., Paleniki, D., Oštrić, N. (2013): Geološka karta i tumač geološke karte Istarske županije. Arhitektonsko-građevni kamen (Geological map and legend of geological map for Istarska County). In: Miko, S., Kruk, B., Dedić, Ž., Kruk, LJ., Peh, Z., Kovačević-Galović, E. and Gabrić, A. (2013): Rudarsko-geološka studija potencijala i gospodarenja mineralnim sirovinama Istarske županije (Mining-geological study of potential and management of raw materials in the Istarska County). Hrvatski geološki institut, Zagreb (in Croatian).

Muralha, J., Grasselli, G., Tatone, B., Blumel, M., Chryssaanthakis, P., Yujing, J. (2014): ISRM Suggested methods for laboratory determination of the shear strength of rock joints: Revised version. Rock Mechanics and Rock Engineering, 47, 291-302, DOI 10.1007/s00603-013-0519-z.

Navratil, D. (2011): Statistički model osnovnih geometrijskih značajki diskontinuiteta u mezozojskim karbonatnim stijenama (Statistical model of the basic geometric features of discontinuities in mesozoic carbonate rocks). Ph.D. Thesis. Rudarsko-geološko-naftni fakultet Sveučilišta u Zagrebu. (in Croatian with English abstract).

Patton, F. D. (1966): Multiple modes of shear failure in rock. 1.st Congress ISRM Lisbon, 1, 509-513.

Singh, H.K., Basu, A. (2018): Evaluation of existing criteria in estimating shear strength of natural rock discontinuities. Engineering Geology, 232, 171-181, DOI:10.1016/j. enggeo.2017.11.023.

Tang, Z.C., Wong, I.N.Y. (2016): New criterion for evaluating the peak shear strength of rock joints under different contact states. Rock Mechanics and Rock Engineering, 49, 1191-1199, DOI:10.1007/s00603-015-0811-1.

Tang, Z.C., Liu, Q.S. Huang, J.H. (2014): New criterion for rock joints based on three-dimensional roughness parameters. Journal of Central South University, 21, 4653-4659, DOI:10.1007/s11771-014-2473-7.

Tatone, B.S.A, Grasselli, G. (2009): A method to evaluate the three-dimensional roughness of fracture surfaces in brittle geomaterials. Review of Scientific Instruments, 80, 1-10, DOI:10.1063/1.3266964.

Tatone, B.S.A., Grasselli, G (2010): A new 2D discontinuity roughness parameter and its correlation with JRC. International Journal of Rock Mechanics and Mining Science, 47, 8, 1391-1400.

Tse, R, Cruden, D.M. (1979): Estimating joint roughness coefficients. International Journal of Rock Mechanics and Mining Science and Geomechanics Abstracts, 16, 303307, DOI:10.1016/0148-9062(79)90241-9.

Yang, Z.Y., Lo, S.C., Di, C.C. (2001): Reassessing the joint roughness coefficient (JRC) estimation using $Z_{2}$. Rock Mechanics and Rock Engineering, 34, 3, 243-251, DOI: 10.1007/s006030170012.

Zhao, J. (1997): Joint surface matching and shear strength part B: JRC-JMC shear strength criterion. International Journal of Rock Mechanics and Mining Science, 34, 179-185, DOI:10.1016/S0148-9062(96)00063-0. 


\section{SAŽETAK}

\section{Razvoj modela za procjenu posmične čvrstoće diskontinuiteta u masivnim i okršenim vapnencima}

U radu je prikazana problematika procjene posmične čvrstoće diskontinuiteta, koja posebice dolazi do izražaja u masivnim i okršenim vapnencima kod kojih stijenke diskontinuiteta mogu biti izrazito hrapave i nepravilne, s materijalnom ispunom ili bez nje, a za koje se pokazalo da postojeći modeli ne mogu dati zadovoljavajuće rezultate. Karakterističan primjer takvih vapnenaca jest ležište arhitektonsko-građevnoga kamena „Kanfanar” koje se nalazi na Istarskome poluotoku u Hrvatskoj. Za potrebe razvoja modela za procjenu posmične čvrstoće diskontinuiteta provedena su terenska istraživanja tijekom kojih su pripremljeni veliki uzorci blokova s prirodnim diskontinuitetima te uzorci materijala ispune u graničnim stanjima, na kojima su zatim provedena detaljna laboratorijska ispitivanja posmičnih čvrstoća. Posebna pozornost posvećena je određivanju koeficijenta hrapavosti pukotina $J R C$, stvarnoj kontaktnoj površini između stijenki diskontinuiteta, baznomu, odnosno rezidualnomu kutu trenja te kutu trenja ugrađenoga materijala ispune između ploha diskontinuiteta. Razvoj modela za procjenu posmične čvrstoće diskontinuiteta temeljio se na Bartonovu JRC-JCS empirijskome modelu, s obzirom na činjenicu da je to jedan od najčešće primjenjivanih modela u inženjerskoj praksi. Na temelju rezultata provedenih ispitivanja modificiran je Bartonov JRC-JCS model tako da je umjesto baznoga ili rezidualnoga kuta trenja primijenjen kut trenja ugrađenoga materijala ispune za slučaj diskontinuiteta s ispunom. Uz navedeno, za ispravno vrednovanje hrapavosti stijenki diskontinuiteta u masivnim i okršenim vapnencima utvrđena je nužnost povećanja koeficijenta hrapavosti pukotina $J R C_{10}$ na veće vrijednosti od 20 , koliko su do sada bile predložene kao maksimalno moguće. Evaluacija predloženoga modela pokazala je zadovoljavajuću točnost prilikom procjene posmične čvrstoće diskontinuiteta s materijalom ispune različitoga stanja konzistencije.

\section{Ključne riječi:}

krš; diskontinuitet; posmična čvrstoća; koeficijent hrapavosti pukotine; glinovita ispuna

\section{Author's contribution}

Ivana Dobrilović (1) (PhD student, Mining Engineering) performed the laboratory tests, provided interpretations and the presentation of the results. Petar Hrženjak (2) (PhD, Associated professor, Mining Engineering) performed the field work and laboratory tests, provided interpretations and the presentation of the results. Dražen Navratil (3) (PhD, Geology Engineering) performed the field work and the digitalisation of joint profiles. 